\title{
The Effect of Parenting Program on Knowledge and Attitudes of Parents in Fulfillment The Basic Needs of Children in Karangtanjung Village
}

\author{
Masfa'if Riandi, Nashri Maulidah, Tria Mugi Safitri, Suhartono \\ Universitas Sebelas Maret \\ masfaif.riandi@gmail.com
}

\section{Article History}

accepted 24/09/2019

\begin{abstract}
Giving a device to children who are too early is one example of parents' indifference to the child's development. This is due to the lack of knowledge and understanding of parents in educating and caring for children in the family. This study aims to analyze the effect of parenting programs on the knowledge and attitudes of parents in meeting the basic needs of children in Karangtanjung Village. This research is a descriptive study with the subject of research are 10 parents with different professional backgrounds in Karangtanjung Village. The research instrument used in the form of pretest and posttest questions, questionnaires, and interviews. The data analysis technique uses descriptive qualitative. The results showed that the existence of the Parenting Program can: (1) Increase parents 'knowledge of correct parenting according to the stage of child development, (2) Increase parents' concern for balanced nutrition which is important for children's growth and development. (3) Increase parents 'understanding of the importance of parents' participation in the child's learning process at home.
\end{abstract}

Keywords: Parenting program, parents' knowledge and attitude, the fulfillment of basic needs

\begin{abstract}
Abstrak
Pemberian gawai kepada anak yang terlalu dini merupakan salah satu contoh dari ketidakpedulian orang tua terhadap perkembangan anak. Hal ini disebabkan kurangnya pengetahuan dan pemahaman orang tua dalam mendidik dan mengasuh anak di dalam keluarga. Penelitian ini bertujuan untuk menganalisis pengaruh program parenting terhadap pengetahuan dan sikap orang tua dalam pemenuhan kebutuhan dasar anak di Desa Karangtanjung. Penelitian ini merupakan penelitian deskriptif dengan subjek penelitian adalah 10 orang tua dengan latar belakang profesi yang berbeda di Desa Karangtanjung. Instrument penelitian yang digunakan berupa lembar soal pretest dan postest, angket, dan wawancara. Teknik analisis data menggunakan deskriptif kualitatif. Hasil penelitian menunjukkan bahwa adanya Program Parenting dapat: (1) Meningkatkan pengetahuan orang tua akan pola asuh yang benar sesuai tahap perkembangan anak, (2) Meningkatkan kepedulian orang tua terhadap asupan gizi seimbang yang penting untuk tumbuh kembang anak. (3) Meningkatkan pemahaman orang tua mengenai pentingnya keikutsertaan orang tua dalam proses belajar anak di rumah.
\end{abstract}

Kata kunci: Program Parenting, pengetahuan dan sikap orang tua, kebutuhan dasar anak

Social, Humanities, and Education Studies (SHEs): Conference Series https://jurnal.uns.ac.id/shes

p-ISSN 2620-9284

e-ISSN 2620-9292 


\section{PENDAHULUAN}

Menurut UU No. 20 tahun 2003 tentang Sistem Pendidikan Nasional disebutkan bahwa bahwa pendidikan merupakan usaha sadar dan terencana untuk mewujudkan suasana belajar dan proses pembelajaran agar peserta didik secara aktif mengembangkan potensi dirinya untuk memiliki kekuatan spiritual keagamaan, pengendalian diri, kepribadian, kecerdasan, akhlak mulia, serta keterampilan yang diperlukan dirinya, masyarakat, bangsa dan negara. Pendidikan merupakan tanggung jawab bersama antara keluarga, masyarakat dan pemerintah yang merupakan tri pusat pendidikan.

Keluarga merupakan pendidik pertama dan paling utama yang memiliki peran strategis dalam mendukung penyelenggaraan pendidikan demi tercapainya tujuan pendidikan nasional. Keluarga memiliki peranan penting untuk memberikan dasar pendidikan, sikap serta keterampilan dasar, seperti: pendidikan agama, budi pekerti, sopan santun, estetika, kasih sayang, rasa aman, dasar-dasar untuk mematuhi peraturan-peraturan, dan menanamkan kebiasaan-kebiasaan. Selain hal tersebut, keluarga memiliki kewajiban mengajarkan nilai-nilai dan tingkah laku sesuai dengan norma-norma yang berlaku di masyarakat.

Namun, pada kenyataannya masih banyak orang tua yang mendidik putraputrinya dengan pola asuh yang otoriter. Mereka cenderung menyuruh anak-anak mereka untuk melakukan sesuatu namun tidak dengan memberikan contoh ataupun pendampingan. Sehingga menjadikan anak mereka suka marah dan susah untuk diatur. Orang tua kurang begitu terlibat dalam penanaman sikap serta kepribadian anak di rumah dan lebih memberikan tanggung jawab pendidikan kepada pihak sekolah.

Oleh karena itu, pemerintah sebagai pemangku kebijakan mengeluarkan Permendikbud No. 30 tahun 2017 tentang Pelibatan Keluarga pada Penyelenggaraan Pendidikan sehingga dengan adanya pelibatan keluarga dapat mendorong penguatan pendidikan karakter anak dan meningkatkan kepedulian keluarga terhadap pendidikan anak. Bentuk pelibatan keluarga dalam lingkungan keluarga ini dapat berupa menumbuhkan nilai-nilai karakter anak di lingkungan keluarga, memotivasi semangat belajar anak, mendorong budaya literasi dan memfasilitasi kebutuhan belajar anak.

Dalam masa pertumbuhan anak sangat diperlukan pemenuhan kebutuhan dasar secara optimal berupa asupan gizi seimbang, perlindungan kesehatan, asuhan penuh kasih sayang dan rangsangan pendidikan yang sesuai dengan tahap perkembangan dan kemampuan masing-masing anak. (Setijaningsih dan Martiningsih, 2014)

Sementara itu, tidak semua orang tua memiliki pengetahuan yang cukup dalam mendidik putra-putrinya di rumah. Apalagi pada zaman modern sekarang ini penggunaan gawai oleh anak-anak tidak hanya di daerah perkotaan namun semakin merambah ke daerah pedesaan. Seperti yang di Desa Karangtanjung yang terletak di daerah pedesaan. Banyak anak yang sering bermain gawai namun tidak didampingi oleh orang tua mereka. Orang tua juga merasa kurang bisa mengontrol anaknya. Kebanyakan orang tua bersikap terlalu memanjakan anak, bersikap cuek kepada anak dan terkadang juga bersikap kasar kepada anak. Hal ini terjadi karena latar belakang pendidikan orang tua yang masih rendah sehingga pengetahuan dan sikap orang tua dalam pola asuh yang diberikan kepada anak kurang sesuai dengan karakteristik tahap perkembangan anak.

Anak usia sekolah dasar (7-12 th) sedang berada pada tahap perkembangan operasional konkret. Menurut Jarvis (2009), pada tahap ini anak sudah cukup matang untuk menggunakan pemikiran logika atau operasi, tetapi hanya untuk objek fisik yang ada saat ini. Namun, tanpa objek fisik di hadapan mereka, anak-anak pada tahap operasional konkret masih mengalami kesulitan besar dalam menyelesaikan tugastugas logika. Mereka dapat memahami sesuatu apabila ada contoh benda yang konkret atau nyata. Selain itu, menurut Burhaein (2017), anak usia sekolah dasar 
memiliki karakteristik yaitu senang bermain, senang bergerak, senang beraktifitas kelompok, dan senang praktik langsung.

Pola asuh merupakan cara orang tua memperlakukan anaknya dengan menjaga, merawat, dan mendidik anaknya. Menurut Komariah (2015) terdapat beberapa jenis pola asuh yang diberikan orang tua kepada anaknya di dalam keluarga yaitu.

1. Authoritative atau pola asuh demokratis yaitu pola asuh yang memprioritaskan kepentingan anak akan tetapi tidak ragu-ragu mengendalikan. Orang tua bersikap rasional, selalu mendasari tindakannya pada rasio atau pemikiran-pemikiran. Orang tua yang demokratis memandang sama kewajiban hak orang tua dan anak, bersikap rasional dan selalu mendasari tindakannya pada rasio pemikiran.

2. Authoritarian atau pola asuh otoriter merupakan pola asuh dengan kecenderungan menetapkan standar yang mutlak harus dituruti, biasanya disertai dengan ancamanancaman. Menekan pada pengawasan orang tua atau kontrol yang ditunjukkan pada anak untuk mendapatkan kepatuhan dan ketaatan. Orang tua sangat berkuasa terhadap anak, memegang kekuasaan tertinggi serta mengharuskan anak patuh pada perintah-perintahnya

3. Indulgent atau pola asuh permisif Atau pemanja adalah suatu bentuk pengasuhan dimana orang tua memberikan kebebasan sebanyak mungkin kepada anak untuk mengatur dirinya, anak tidak dituntut untuk bertanggung jawab dan tidak banyak kontrol oleh orang tua

4. Indifferent atau pola asuh tipe penelantar yaitu pola asuh dimana orang tua biasanya memiliki interaksi waktu yang sedikit dengan anak-anaknya sehingga anak dibiarkan berkembang fisik dan psikisnya.

Oleh karena itu, agar orang tua dapat menjadi pendidik bagi anak di rumah penting untuk diadakannya program parenting. Program parenting merupakan suatu program untuk memberikan informasi pengetahuan tentang tumbuh kembang anak serta pengasuhan anak agar orang tua paham dalam memberikan pengasuhan kepada anak yang harus sesuai dengan masa pertumbuhan dan perkembangan anak tersebut. (Ningsih, dkk., 2018) Pelaksanaan pendidikan dengan memberdayakan orang tua merupakan solusi yang baik guna meningkatkan mutu pendidikan anak di lingkungan keluarga.

Berdasarkan latar belakang inilah penulis melakukan penelitian agar mengetahui pengaruh program parenting terhadap pengetahuan dan sikap orang tua dalam pemenuhan kebutuhan dasar anak di Desa Karangtanjung.

\section{METODE}

Penelitian ini merupakan penelitian deskriptif yang dilakukan untuk memperoleh gambaran mengenai pengaruh program parenting terhadap pengetahuan dan sikap orang tua dalam pemenuhan kebutuhan dasar anak di Desa Karangtanjung. Penyampaian materi program parenting dilakukan dengan metode ceramah dan tanya jawab. Instrumen penelitian ini terdiri dari lembar pretest, posttest, angket dan wawancara yang diadopsi dari Kebijakan Teknis Pelibatan Keluarga dan Masyarakat di Satuan Pendidikan yang disampaikan oleh Kementerian Pendidikan dan Kebudayaan. Subjek penelitian adalah 10 orang ibu yang memiliki anak usia sekolah dasar dengan latar belakang profesi yang berbeda. Teknik analisis data menggunakan reduksi data, display data, dan penarikan kesimpulan.

Untuk mencari besar presentase keberhasilan menggunakan persamaan berikut.

$$
\text { Presentase Keberhasilan }(p)=\frac{\text { Skoryang didapatkan }}{\text { Skor Maksimal }} \times 100 \%
$$


HASIL DAN PEMBAHASAN

Program parenting berbasis keluarga merupakan program dukungan yang ditujukan kepada para orang tua atau anggota keluarga lain agar semakin memiliki pengetahuan dan kemampuan dalam mengasuh, merawat, melindungi dan mendidik anaknya di rumah sehingga anak dapat tumbuh dan berkembang secara optimal sesuai usia dan tahap perkembangannya. Manfaat kegiatatan parenting, yaitu dapat membangun komunikasi yang baik antara lembaga dengan orang tua. Sehingga pola pengasuhan yang dijalankan di lembaga dengan yang diterapkan orang tua dirumah selaras, melalui kegiatan parenting juga orangtua dapat mengetahui capaian perkembangan anak, hak-hak dasar apa saja yang harus dipenuhi orang tua dalam kelangsungan hidup anak, dan memberikan pengetahuan kepada orang tua (Ganevi, 2013).

\section{Pelaksanaan Program Parenting di Lingkungan Masyarakat}

Metode yang digunakan dalam pelaksanaan program parenting di Desa Karangtanjung yaitu metode ceramah dan tanya jawab. Hal ini dilakukan agar antara pembicara dan peserta parenting dapat berinteraksi dengan baik. Media yang digunakan yaitu modul yang berjudul modul program parenting yang berisi pemahaman pola asuh, gizi seimbang, dan psikologi anak. Semua materi tersebut sesuai dengan Kebijakan Teknis Pelibatan Keluarga dan Masyarakat di Satuan Pendidikan yang disampaikan oleh Kementerian Pendidikan dan Kebudayaan. Pelaksanaan program parenting bertempat di salah satu rumah warga di Desa Karangtanjung dengan konsep lesehan. Program ini ditujukan kepada orang tua yang mempunyai anak sekolah dasar sebagai pesertanya yang dilaksanakan pada hari Jumat tanggal 27 September 2019 pukul 14.30-16.30 WIB. Proses pelaksanaan program parenting meliputi pembukaan, pretest, penyampaian materi, posttest, pengisian angket dan wawancara. Jumlah responden sebanyak 10 orang yang memiliki latar belakang profesi dan pengetahuan yang berbeda. Sebanyak $20 \%$ berprofesi sebagai pedagang dan selebihnya sebagai ibu rumah tangga. berdasarkan pengamatan hanya $10 \%$ dari jumlah responden yang sudah pernah mengikuti kegiatan parenting.

\section{Meningkatkan Pengetahuan Orang tua akan Pola Asuh yang Benar Sesuai Tahap Perkembangan Anak Sebesar yaitu 12\% yang Diperoleh dari Hasil Posttest}

Menurut Notoatmodjo dalam Setijaningsih dan Mariningsih (2014) pengetahuan adalah merupakan hasil "tahu" dan ini terjadi setelah orang mengadakan penginderaan terhadap suatu objek tertentu. Penginderaan terhadap obyek terjadi melalui panca indra manusia yakni penglihatan, pendengaran, penciuman, rasa dan raba dengan sendiri. Partisipasi orang tua merupakan tingkat kerjasama yang lebih luas dan tinggi tingkatannya. Orang tua dan sekolah duduk Bersama untuk membicarakan berbagai program dan kegiatan anak. Orang tua datang ke sekolah untuk membantu guru melaksanakan tugas-tugas rutin, seperti menyiapkan makanan, menyiapkan alat/media yang dibutuhkan untuk pembelajaran, dan ikut menjadi keamanan. Berdasakan pretest yang telah dilakukan menghasilkan rata-rata presentase keberhasilan sebesar $65 \%$ dan pada hasil posttest $77 \%$, sehingga terjadi peningkatan sebesar $12 \%$. Hal ini menunjukkan bahwa adanya sosialisasi program parenting dengan pemberian modul dan penjelasan materi dapat meningkatkan pengetahuan orang tua mengenai pola asuh, gizi seimbang dan psikologi anak. Semua materi yang disampaikan bisa terserap dan memberikan dampak baik terhadap orang tua kepada anak. Hal ini dapat diketahui berdasarkan hasil wawancara yang telah dilakukan setelah pengerjaan posttest.

\section{Meningkatkan Kepedulian Orang tua terhadap Asupan Gizi Seimbang yang Penting Untuk Tumbuh Kembang Anak}

Menurut Permenkes nomor 41 tahun 2014 menyatakan bahwa pola makan merupakan perilaku paling penting yang dapat mempengaruhi keadaan gizi. Hal ini disebabkan karena kuantitas dan kualitas makanan dan minuman yang dikonsumsi 
akan mempengaruhi asupan gizi sehingga akan mempengaruhi kesehatan individu dan masyarakat. Berdasarkan wawancara yang dilakukan menunjukkan perubahan perilaku yang sebelumnya tidak memperhatikan asupan gizi menjadi lebih memperhatikan dengan pembiasaan sarapan pagi yang terdiri dari pangan karbohidrat, pangan lauk pauk, sayuran atau buah-buahan dan minuman. Dengan asupan tersebut orang tua di Desa Karangtanjung berharap anak mereka bisa tumbuh dan berkembang sesuai dengan usianya. Selain itu, orang tua berharap anak menjadi pintar, matang dalam berpikir dan bertindak. Hal tersebut sesuai dengan Permenkes nomor 41 tahun 2014 yaitu bagi anak sekolah, sarapan yang cukup terbukti dapat meningkatkan konsentrasi belajar dan stamina. Menurut Setijaningsih dan Mariningsih (2014) sikap merupakan suatu kencenderungan untuk bertindak secara suka atau tidak suka terhadap suatu objek. Sikap dapat dibentuk melalui cara mengamati dan menirukan sesuatu yang positif, kemudian melalui penguatan serta menerima informasi verbal. Perubahan sikap dapat diamati dalam proses pembelajaran, tujuan yang ingin dicapai, keteguhan, dan konsistensi terhadap sesuatu. Fenomena sikap yang timbul tidak saja ditentukan oleh keadaan objek yang sedang dihadapi tetapi juga ada kaitannya dengan pengalaman-pengalaman masa lalu, oleh situasi di saat sekarang, dan oleh harapan untuk masa yang akan datang. Menurut Azwar dalam Setijaningsih dan Mariningsih (2014) menyimpulkan bahwa faktor-faktor yang mempengaruhi pembentukan sikap adalah pengalaman pribadi, kebudayaan, orang lain yang dianggap penting, media massa, institusi atau lembaga pendidikan dan lembaga agama, serta faktor emosi dalam diri individu.

\section{Meningkatkan Pemahaman Orang tua Mengenai Pentingnya Keikutsertaan Orang tua dalam Proses Belajar Anak di Rumah}

Hasil wawancara menunjukkan bahwa pola asuh orang tua sebelum dilakukannya kegiatan sosialisasi parenting dominan menggunakan pola asuh otoriter. Mereka terlalu sering memerintah anak untuk rajin belajar, akan tetapi orang tua tidak ikut mendampingi anak dalam kegiatan belajar di rumah. Sehingga ketika anak belajar, orang tua tidak tahu kegiatan belajar seperti apakah yang sedang dilakukan oleh anak tersebut. Orang tua juga tidak tahu pada tahap apakah kemampuan belajar yang dimiliki oleh sang anak. Kendala-kendala yang dimiliki anak pun tidak diketahui oleh orang tua. Sehingga ketika anak menolak untuk belajar, orang tua hanya melampiaskan emosi dalam bentuk amarah kata-kata yang menjadikan anak lebih tidak berminat untuk belajar. Padahal anak dalam tahap perkembangan sekolah dasar tidak suka terlalu banyak kekangan. Mereka lebih senang bermain sambil belajar dan lebih senang bergerak, senang bekerja kelompok dan senang praktek langsung. Oleh karena itu, orang tua sebagai pendidik pertama dan utama bagi anak haruslah paham dengan karakteristik tersebut. Akan tetapi banyak orang tua yang belum memahami karakteristik tersebut. Oleh karena itu, setelah diadakannya sosialisasi mengenai parenting ini dapat menambah pemahaman orang tua akan pentingnya keikutsertaan orang tua dalam proses belajar anak. Sehingga mereka bersedia menemani putraputrinya dalam kegiatan belajar anak dalam lingkungan keluarga.

\section{SIMPULAN}

Setelah diadakannya program parenting yang dlaksanakan di Desa Karangtanjung dapat disimpulkan bahwa terdapat pengaruh program parenting terhadap pengetahuan dan sikap orang tua dalam pemenuhan kebutuhan dasar anak. Dengan adanya program parenting dapat (1) Meningkatkan pengetahuan orang tua akan pola asuh yang benar sesuai tahap perkembangan anak sebesar yaitu $12 \%$ yang diperoleh dari hasil posttest (2) Meningkatkan kepedulian orang tua terhadap asupan gizi seimbang yang penting untuk tumbuh kembang anak. (3) Meningkatkan pemahaman orang tua mengenai pentingnya keikutsertaan orang tua dalam proses belajar anak di rumah. 
DAFTAR PUSTAKA

Burhaen, E. (2017). Aktivitas Fisik Olahraga untuk Pertumbuhan dan Perkembangan Siswa SD. Indonesian Journal of Primary Education Vol 1 No 1 Tahun 2017. Diakses dari http://ejournal.upi.edu/index.php/lJPE/article/download/7497/4860 tanggal 23 September 2019.

Dewan Perwakilan Rakyat RI dan Presiden RI. (2003). Undang-Undang Republik Indonesia Nomor 20 Tahun 2003 Tentang Sistem Pendidikan Indonesia. Jakarta: Sekretaris Negara RI.

Ganevi, N. (2013). Pelaksanaan Program Parenting bagi Orang Tua dalam Menumbuhkan Perilaku Keluarga Ramah Anak (Studi Deskriptif di Pendidikan Anak Usia Dini Al-Ikhlas Kota Bandung). Jurnal Pendidikan Luar Sekolah Vol. 9 $\begin{array}{llll}\text { Nomor } & 2 & \text { Tahun } 2013 . & \text { Diakses dari }\end{array}$ http://ejournal.upi.edu/index.php/pls/article/download/5425/3721 tanggal 10 Sepetember 2019.

Jarvis, M. (2009). Teori-teori Psikologi: Pendekatan Modern untuk Memahami Perilaku, Perasaan \& Pikiran Manusia. Bandung: Nusamedia.

Kementrian Kesehatan Republik Indonesia. (2014). Peraturan Menteri Kesehatan Republik Indonesia tentang Pedoman Gizi Seimbang (Permenkes Nomor 41 tahun 2014). Jakarta: Penulis.

Komariah, Y. (2015). Efektivitas Program Pelatihan Parenting Skill terhadap Peningkatan Pemahaman Orang tua tentang Pola Asuh. Journal Bimbingan dan Konseling Islam Volume 5 Nomor 2 Tahun 2015. Diakses dari http://jurnalbki.uinsby.ac.id/index.php/jurnalbki/article/view/41/pdf 8 pada tanggal 10 September 2019.

Ningsih, F. D., dkk. (2018). Pelaksanaan Program Parenting di Lembaga Paud Kecamatan Basa Ampek Balai Tapan. Jurnal IImiah Potensia Vol. 3 (1) Tahun 2018.

Diakses

dari https://ejournal.unib.ac.id/index.php/potensia/article/download/1759/2686 tanggal 18 September 2019.

Setijaningsih, T., dan Martiningsih, W. (2014). Pengaruh Program Parenting terhadap Pengetahuan dan Sikap Orang Tua dalam Pemenuhan Kebutuhan Dasar Anak Usia Dini. Jurnal Ners dan Kebidanan Vol. 1 No. 2 Tahun 2014. Diakses dari https://media.neliti.com/media/publications/232672-the-effect-of-parentingprogram-towards-4233e85c.pdf tanggal 11 September 2019. 